\title{
SOIL ATTRIBUTES UNDER AGROECOSYSTEMS AND FOREST VEGETATION IN THE COASTAL TABLELANDS OF NORTHESTERN BRAZIL
}

\author{
Atributos de solo de agroecossistemas e coberturas florestais dos \\ tabuleiros costeiros do nordeste do Brasil
}

\author{
João Bosco Vasconcellos Gomes'1, Marcelo Ferreira Fernandes², Antonio Carlos Barreto², \\ José Coelho de Araújo Filho ${ }^{3}$, Nilton Curi ${ }^{4}$
}

\begin{abstract}
This study evaluated the changes occurred in a set of soil attributes, particularly those related to the dynamics of soil organic carbon (SOC), as a function of the replacement of native forest for agricultural ecosystems of regional importance in the coastal tablelands of Northeastern Brazil (orange, coconut, eucalyptus and sugarcane). Six commercial sites under these agroecosystems were compared to neighboring areas of native forest in five areas along this region (Coruripe, Umbaúba, Acajutiba, Cruz das Almas and Nova Viçosa). Soil samples were taken from 0-5 and 5-20 cm depth and analyzed for particle size distribution, bulk density, organic C (OC), particulate organic matter, $\mathrm{C}$ in soil solution, microbial biomass $\mathrm{C}$, total cation exchange capacity and water stable aggregates. Linear correlation and multivariate techniques were used for data analysis. The values of base saturation and $\mathrm{Al}$ saturation for the $0-20 \mathrm{~cm}$ depth layer were also calculated. In all the studied areas, soils under native forest presented better status of physical and chemical attributes than their agroecosystem counterparts, especially in the $0-5 \mathrm{~cm}$ layer. For both layers, OC content was the attribute most strongly correlated with the overall changes in all attributes. Unexpectedly, the OC content showed no significant correlation with the sum of silt and clay contents. The set of variables investigated in this study is sensitive to differentiate the quality of soils under perennial and semi-perennial land uses from their counterparts under natural vegetation in the landscapes of the coastal tablelands of Northeastern Brazil.
\end{abstract}

Index terms: Cohesive soils, organic $\mathrm{C}$, coastal tablelands, kaolinitic soils.

\section{RESUMO}

Este trabalho avaliou as alterações de um conjunto de atributos de solos dos tabuleiros costeiros do Nordeste do Brasil, em especial os relacionados à dinâmica do $\mathrm{C}$ orgânico $(\mathrm{CO})$, em função da substituição da vegetação florestal nativa por agroecossistemas de importância regional (laranja, coco, eucalipto e cana-de-açúcar). Seis sítios comerciais sob esses agroecossistemas foram comparados a áreas vizinhas de mata nativa, em cinco locais de amostragem ao longo dos tabuleiros costeiros (Coruripe, Umbaúba, Acajutiba, Cruz das Almas e Nova Viçosa) Foram coletadas amostras de solo de 0-5 e de 5-20 cm de profundidade para determinar granulometria, densidade do solo, C orgânico (CO), matéria orgânica particulada, $\mathrm{C}$ da solução do solo, $\mathrm{C}$ da biomassa microbiana, capacidade de troca catiônica e agregados estáveis em água. Para análise dos dados foram realizadas correlações lineares e análises multivariadas. Os valores de saturação por bases e por Al da camada de 0-20 cm também foram calculados. Em todos os locais, a vegetação com floresta nativa apresentou maior qualidade de atributos químicos e físicos do solo do que os respectivos sistemas agrícolas, principalmente na camada de 0-5 cm. Para as duas camadas, o atributo que explicou a maior parte da variação dos dados, em função do conjunto de atributos estudados, foi o CO. Este, inesperadamente, não apresentou correlação significativa com a soma dos teores de silte e argila. O conjunto das variáveis analisadas é sensível para diferenciar a qualidade dos solos sob uso com espécies perenes e semiperenes do solo de seus correlatos sob vegetação natural nas paisagens de solos dos tabuleiros costeiros do Nordeste do Brasil.

Termos para indexação: Caráter coeso, C orgânico, tabuleiros costeiros, solos cauliníticos.

(Received in august 24, 2012 and approved in october 5, 2012)

\section{INTRODUCTION}

Coastal tablelands are plateaus of sedimentary origin from the Tertiary period, referred to as the Barreiras Group, that present a degree of scoring and variable climate and which accompany the Brazilian coast between the states of Rio de Janeiro and Maranhão. The landscapes of the coastal tablelands occupy approximately $111,000 \mathrm{~km}^{2}$ of the Brazilian states (SILVA et al., 1993; JACOMINE, 2001), being strategic for their proximity to large urban centers and for sustaining, in the range under domain of phytoecological forest units, industrial scale agricultural uses (sugarcane and reforestation with eucalyptus), pastures of quite varied quality and areas with irrigated and rainfed fruit

\footnotetext{
Empresa Brasileira de Pesquisa Agropecuária/Embrapa - Embrapa Florestas - Colombo - PR - Brasil

${ }^{2}$ Empresa Brasileira de Pesquisa Agropecuária/Embrapa - Embrapa Tabuleiros Costeiros - Aracaju - SE - Brasil

${ }^{3}$ Empresa Brasileira de Pesquisa Agropecuária/Embrapa - Embrapa Solos - Recife - PE - Brasil

${ }^{4}$ Universidade Federal de Lavras/UFLA - Departamento de Ciência do Solo/DCS - Cx.P. 3037 - 37200-000 - Lavras - MG - Brasil - niltcuri@ufla.br
} 
production (EMPRESA BRASILEIRA DE PESQUISA AGROPECUÁRIA-EMBRAPA, 2005; LANI, 2008).

The predominance of soil uses with perennial and semi-perennial species is consistent with fragilities associated to the characteristics of the local soils, mainly when they avoid the constant soil tillage (GOMES et al., 2008). A part of that fragility can be explained by the kaolinitic mineralogy of the clay fraction, which translates into a low level of macrostructure (FERREIRA; FERNANDES; CURI, 1999; JUO; FRANZLUEBBERS, 2003; RESENDE et al., 2011). Kaolinitic soils occur on savannah landscapes (GOMES et al., 2004), but these associate coarse texture (medium sandy) with relatively higher Fe oxide content, or present relatively lower kaolinite/gibbsite ratios than the soils of the Brazilian coastal tablelands (DUARTE et al., 2000).

This kaolinitic mineralogy should also be considered in the common presence of cohesive layers in the subsurface of the coastal tableland soils. The formation of those layers (cohesive horizons) occurs in a natural way and can be associated to several processes, such as: blockage of the pores with illuvial clay; presence of organic compounds little polymerized; presence and accumulation of secondary silica, $\mathrm{Fe}$ oxides and clay dispersed in the micropores; and densification by desiccation resulting from the alteration of the soil structure by the alternation of soil wetting and drying cycles (CORRÊA et al., 2008; GIAROLA et al., 2009; LIMA NETO et al., 2009). The cohesion is more intense in the driest periods (CINTRA et al., 2009) and in the more clayey soils. The combination of cohesive layers in subsurface, predominance of weak degree soil macro-structure and high laminate erosion rates provokes fast degradation of the superficial horizon when it is submitted to the constant tilling (annual), even in the presence of flat and gentle rolling reliefs (RESENDE et al., 2011). Chaer et al. (2009), working with soils of coastal tablelands of Sergipe found fast deterioration of various attributes of surface soil (organic matter, soil density, saturated hydraulic conductivity, cation exchange capacity, water stable aggregates etc.) in response to the increase of the number of soil preparation operations.

Considering the fragilities described for the soils of coastal tablelands, the evaluation of various soil attributes the among areas under different agroecosystems (mainly perennial and the semi-perennial crops) and their respective natural systems make up an important strategy to diagnose the impact of these agricultural activities on the soil quality in the area. The types of attributes involved in those studies are varied, with a strong current tendency for the integration of physical, chemical and biological attributes (CHAPMAN; CAMPBELL; PURI, 2003; ZORNOZA et al., 2007; CHAER et al., 2009), it being common to emphasize organic $\mathrm{C}(\mathrm{OC})$ and attributes that qualify or compartmentalize it as indicators in the concept of the quality of a soil (SHUKLA et al., 2006).

In these studies, those variables that are useindependent should also be contextualized. Although very homogeneous in mineralogical terms (kaolinitic), the soils of coastal tablelands can present variations in the landscape dissection degree and position, in the local rains distribution and in the soil texture. The soil texture variations of the tablelands are erratic and very pronounced (ZANGRANDE; REZENDE, 1989). To reduce the effect of these factors, little to not alterable by the land use, on the interpretation of the impacts of the different agroecosystems on the soil quality, we can pair sites evaluated under agricultural use with sites under natural vegetation (primary or secondary forests), with the latter representing a local reference condition.

The decrease of the coastal tableland soil quality after the substitution of the forest by agricultural use, considering quantifications of its superficial and subsuperficial horizons, has been reported in specific studies, with obvious effects on the organic matter pools and associated variables (cation exchange capacity, water stable aggregates and average aggregate diameter) (SILVA et al., 2006a; SILVA et al., 2006b; COSTA et al., 2009; SANT'ANNA et al., 2009; FERNANDES et al., 2011; PACHECO; CANTALICE, 2011), however there is a lack of studies including a wider geographical sampling.

As such, the objective of this work was to evaluate the alterations of a group of chemical, physical and microbiological attributes, with emphasis for those related to OC dynamics, of the $0-5$ and $5-20 \mathrm{~cm}$ superficial soil layers of the Northeastern Brazilian coastal tablelands derived from the substitution of the natural forest vegetation by agroecosystems of regional importance (sugarcane, eucalyptus, orange tree and coconut tree).

\section{MATERIAL AND METHODS}

\section{Study areas and soil description}

Five areas of coastal tablelands were selected for the study (Figure 1). The study areas are in the states of Bahia (BA), Sergipe (SE) and Alagoas (AL), where the coastal tablelands comprise approximately $52,911 \mathrm{~km}^{2}$. The areas Nova Viçosa-BA (V) and Cruz das Almas-BA (R) present tropical climate with all of the months rainy (the driest month with more than $60 \mathrm{~mm}$ of rain). The areas Coruripe-AL (C), 
Umbaúba-SE (U) and Acajutiba-BA (A) are under a rainy tropical climate with dry summer (SILVA et al., 1993).

Table 1 presents the 12 area and land use combinations (groups), between agroecosystems and forests (primary or secondary with variable degrees of alteration). All of the sampling points (sites) of each group represent situations of wide summit to a very gentle slope of coastal tablelands, in flat relief. All of the soils present cohesive character, whose degree and expression depth vary in function of the clay content, the local climate and the $\mathrm{A}$ and $\mathrm{B}$ horizon transition depths.

\section{Sampling and analysis}

The soil samples were collected in the 0-5 and 5$20 \mathrm{~cm}$ deep layers, in the 12 groups defined in table 1 . Each group was sampled in five sites (repetitions), totaling 60 sites for the soil attribute evaluations. For the agroecosystems the samples were collected between plants in the planting rows. Considering the two appraised layers, samples were collected regarding 120 points.

Four groups of samples were obtained: disturbed, for particle size distribution, $\mathrm{OC}$ and cation exchange capacity (CEC); with aggregate preservation, for water stable aggregates (WSA); cooled, for microbial biomass C
(MBC), particulate organic matter (POM) and the soil solution; and of known volume, for bulk density (BD). The disturbed samples were seived in a $2 \mathrm{~mm}$ mesh and airdried. The samples for WSA were sieved in a $4 \mathrm{~mm}$ mesh. The samples of known volume were taken in the central part of the range of each layer.

The particle size distribution, OC, CEC, BD and WSA analyses were determined according to Embrapa (1997). WSA was expressed by the ratio between the mass of dry aggregates retained in a $0.25 \mathrm{~mm}$ sieve after the wet sieving operation in a Yoder apparatus and the total mass of dry soil used in the analysis. CEC was calculated from the sum of the determinations of the exchangeable bases $(\mathrm{Ca}, \mathrm{Mg}, \mathrm{K}$ and $\mathrm{Na}$ ) and potential acidity $(\mathrm{H}+\mathrm{Al})$ (data not shown). Base (V) and $\mathrm{Al}(\mathrm{m})$ saturation values of the exchange complex were calculated for the weighted average of the two layers sampled. POM was estimated from the $\mathrm{C}$ content in the sand fraction (AMELUNG; $\mathrm{ZECH}$; FLACH, 1998). The MBC determination was conducted by the fumigation-extraction method (VANCE et al., 1987), $\mathrm{C}$ in fumigated and non-fumigated soil extracts being determined by the colorimeter method of Bartlett and Ross (1988). Soil:water extracts at a 1:0.5 proportion extracted according to Gomes et al. (2010), simulated the soil solution, where the dissolved organic C (DOC) was determined.
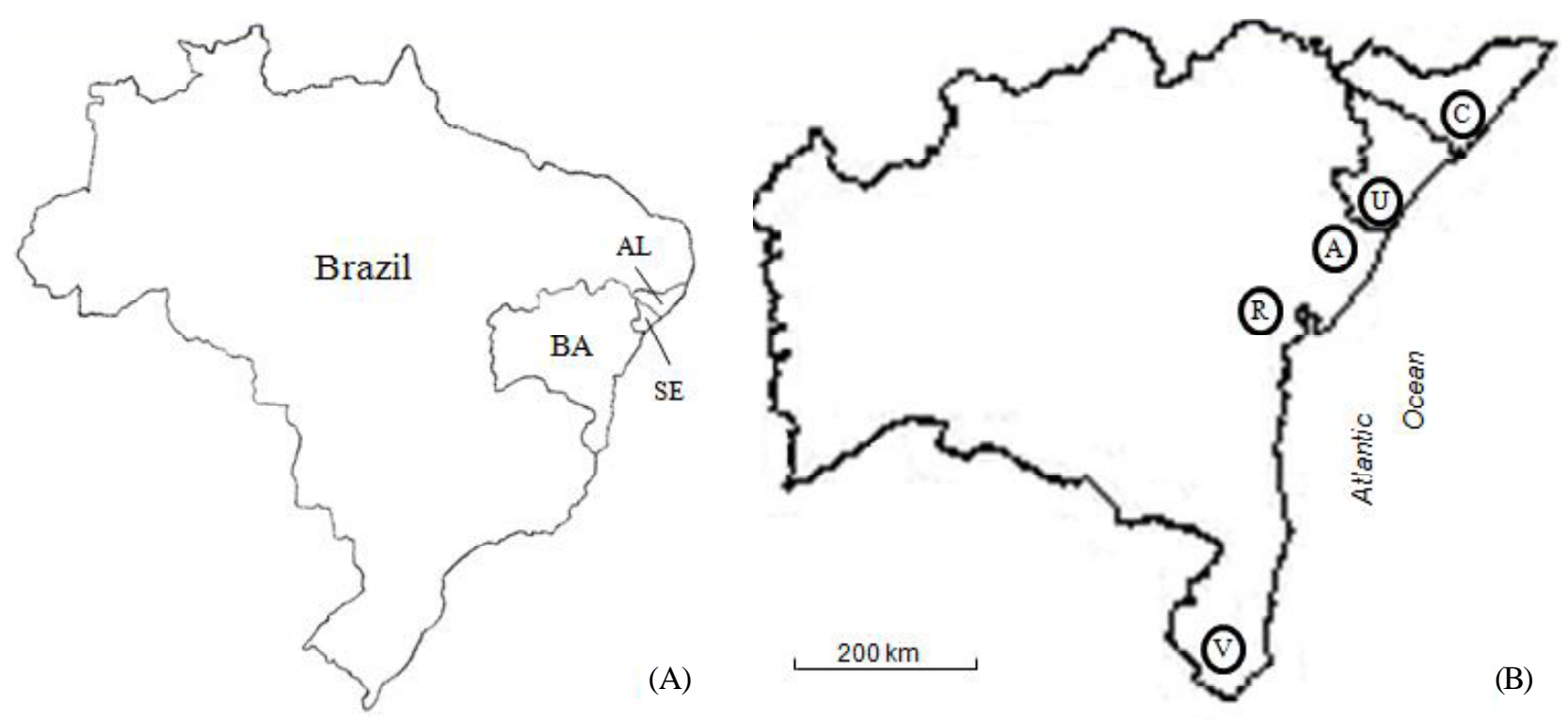

Figure 1 - (A) Map of Brazil showing the states of Alagoas (AL), Sergipe (SE) and Bahia (BA). (B) Map of the states of Alagoas, Sergipe and Bahia, showing the approximate location of the five areas of study: C - Coruripe; U - Umbaúba; A - Acajutiba; R - Cruz das Almas, and V - Nova Viçosa. Average UTM coordinates of each area (24 zone): C - 801.597 $\mathrm{mE}, 8.892 .854 \mathrm{~m} \mathrm{~N}$; U-644.286 m E, 8.741.644 m N; A- 608.112 m E, 8.706.689 m N; R- 489.961 m E, 8.598.978 m N; and $\mathrm{V}-401.947 \mathrm{mE}, 8.032 .788 \mathrm{~m} \mathrm{~N}$.

Ciênc. agrotec., Lavras, v. 36, n. 6, p. 649-664, nov./dez., 2012 
Table 1 - Location and soil characteristics of study areas in agroecosystems and natural forests.

\begin{tabular}{|c|c|c|c|c|}
\hline Groups & Location & Land use & $\begin{array}{c}\text { Soil } \\
\text { classification }^{1} \\
\end{array}$ & Texture \\
\hline $\mathrm{CF}$ & $\begin{array}{l}\text { Coruripe, } \\
\text { AL }\end{array}$ & $\begin{array}{l}\text { Primary forest with a good conservation degree, as } \\
\text { narrow strips between sugarcane areas }\end{array}$ & $\begin{array}{l}\text { PAdx } \\
\text { fragipânico }\end{array}$ & $\begin{array}{c}\text { loamy } \\
\text { sandy/sandy clay } \\
\text { loam/sandy clay }\end{array}$ \\
\hline $\mathrm{C} 1$ & $\begin{array}{l}\text { Coruripe, } \\
\text { AL }\end{array}$ & $\begin{array}{l}\text { Sugarcane, subsoiling, irrigation, 2nd cut after planting, } \\
35 \text { years cropping }\end{array}$ & $\begin{array}{l}\text { PAdx } \\
\text { abrúptico } \\
\text { fragipânico }\end{array}$ & $\begin{array}{l}\text { loamy } \\
\text { sandy/sandy clay } \\
\text { loam/sandy clay }\end{array}$ \\
\hline $\mathrm{C} 2$ & $\begin{array}{l}\text { Coruripe, } \\
\text { AL }\end{array}$ & $\begin{array}{l}\text { Sugarcane, subsoiling, crotalaria, irrigation, } 4 \text { nd cut } \\
\text { after planting, } 40 \text { years cropping }\end{array}$ & $\begin{array}{l}\text { PAdx } \\
\text { abrúptico } \\
\text { fragipânico }\end{array}$ & $\begin{array}{l}\text { loamy } \\
\text { sandy/sandy clay } \\
\text { loam/sandy clay }\end{array}$ \\
\hline UF & $\begin{array}{l}\text { Umbaúba, } \\
\text { SE }\end{array}$ & $\begin{array}{l}\text { Secondary forest with low conservation and } \\
\text { regeneration level }\end{array}$ & PAex típico & $\begin{array}{l}\text { sandy loam/clay } \\
\text { loam }\end{array}$ \\
\hline UO & $\begin{array}{l}\text { Umbaúba, } \\
\text { SE }\end{array}$ & $\begin{array}{c}\text { Orange, } 14 \text { years after planting, intermediate } \\
\text { technological level, various cultural treatments (with } \\
\text { and without subsoiling, green manure between the lines } \\
\text { and harrowing) }\end{array}$ & $\begin{array}{l}\text { PACex } \\
\text { fragipânico }\end{array}$ & $\begin{array}{l}\text { sandy loam/clay } \\
\text { loam }\end{array}$ \\
\hline $\mathrm{AF}$ & $\begin{array}{l}\text { Acajutiba, } \\
\text { BA }\end{array}$ & $\begin{array}{l}\text { Secondary forest with intermediate conservation and } \\
\text { regeneration level }\end{array}$ & $\begin{array}{l}\text { PAdx } \\
\text { latossólico }\end{array}$ & $\begin{array}{c}\text { sandy } \\
\text { loam/sandy clay }\end{array}$ \\
\hline $\mathrm{AE}$ & $\begin{array}{l}\text { Acajutiba, } \\
\text { BA }\end{array}$ & Eucalyptus 3 years after planting & $\begin{array}{l}\text { PAex } \\
\text { latossólico }\end{array}$ & $\begin{array}{c}\text { sandy } \\
\text { loam/sandy clay }\end{array}$ \\
\hline $\mathrm{AC}$ & $\begin{array}{l}\text { Acajutiba, } \\
\text { BA }\end{array}$ & $\begin{array}{c}\text { Coconut, } 25 \text { years after planting, intermediate } \\
\text { technological level }\end{array}$ & $\begin{array}{l}\text { LAdx } \\
\text { argissólico }\end{array}$ & $\begin{array}{c}\text { sandy } \\
\text { loam/sandy clay }\end{array}$ \\
\hline $\mathrm{RF}$ & $\begin{array}{l}\text { Cruz das } \\
\text { Almas, BA }\end{array}$ & $\begin{array}{l}\text { Primary forest with low conservation and regeneration } \\
\text { level, neighbor to an urban area }\end{array}$ & LAdx típico & $\begin{array}{c}\text { sandy clay } \\
\text { loam/sandy clay }\end{array}$ \\
\hline RO & $\begin{array}{c}\text { Cruz das } \\
\text { Almas, BA }\end{array}$ & $\begin{array}{l}\text { Orange, } 5 \text { to } 25 \text { years after ploanting (citrus plots for } \\
\text { over } 40 \text { years), intermediate to high technological level }\end{array}$ & LAdx típico & $\begin{array}{c}\text { sandy clay } \\
\text { loam/sandy clay }\end{array}$ \\
\hline VF & $\begin{array}{c}\text { Nova } \\
\text { Viçosa, BA }\end{array}$ & $\begin{array}{l}\text { Secondary forest, with intermediate to good } \\
\text { conservation and regeneration level }\end{array}$ & $\begin{array}{l}\text { PAdx } \\
\text { abrúptico }\end{array}$ & sandy loam/clay \\
\hline VE & $\begin{array}{c}\text { Nova } \\
\text { Viçosa, BA }\end{array}$ & Eucalypt regrowth 1 year after harvest & PAex típico & sandy loam/clay \\
\hline
\end{tabular}

${ }^{1}$ Order and suborder of the Brazilian system of soil classification - BSSC (Embrapa, 2006): PA - Yellow Argisol, LA - Yellow Latosol. Great group of the BSSC: dx - Distrocoeso, ex - Eutrocoeso.

\section{Statistical analysis}

Initially, the data of each variable were relativized dividing the values of the respective variable in each sample by the sum of the values obtained for all of the samples. This way, we sought to nullify the effect of different of the response variable expression unit magnitudes on the result of the analyses. The linear correlations among the studied variables were determined. The data were analyzed through multivariate analyses. The analyses were conducted separately for each of the layers.

The sites were ordered by the use of non-metric multi-dimensional scaling (NMS), considering seven variables (OC, CEC, BD, WSA, POM, MBC and DOC).
That order allowed the comparison of the different groups (area combination and land use), representing, in the order, the average and the standard deviation regarding the five sites (repetitions) of each group. The sand, silt and clay content were not included at the data matrix used for the ordination analysis by NMS, considering that they are little influenced by land use changes. However, these variables were used to support the interpretation of the variations occurred among the five sampled. NMS was generated by the PC-ORD program version 4 (MCCUNE; MEFFORD, 1999). The analyses were conducted by "autopilot" using the "average" analysis intensity, which includes a maximum number of 200 interactions, instability 
criterion of 0.0001 ; initial number of 4 axes, 15 runs with real data and 30 runs with randomized data. The choice of the number of dimensions of the ordination for optimum NMS to represent differences among the soil quality of the investigated sites was based on the criteria of stability and significance $(\mathrm{p}<0.05)$ of the ordination stress according to the Montecarlo test.

For each local (area) contrasts between land uses under forest and agroecosystems were conducted, through the multi-response permutation procedure (MRPP) technique (MIELKE; BERRY; JOHNSON, 1976), considering the same seven variables used by NMS.

\section{RESULTS AND DISCUSSION}

\section{Samples from 0-5 cm of depth}

Of the 28 pairs of variables tested, non-significant correlations were only observed between the sum of the silt and clay content and the variables OC, CEC, BD, MBC and POM (Table 2). The highest correlation value occurred between OC and CEC $(r=0.83)$. Only BD presented negative correlations with other attributes.

Approximately $94 \%$ of the variability of the analyzed attributes were represented in the two dimensional ordination obtained by the NMS technique, most of this variability being represented along Axis $1(88 \%)$ and only $6 \%$, for Axis 2 (Figure 2 and table 3 ). The distribution of the sites along Axis 1 was positively correlated $(\mathrm{p}<0.001)$ with OC, CEC, WSA, MBC, POM and DOC, and negatively correlated with BD. Thus, it can be admitted a better soil quality of the different sites improving from the left to the right direction of Axis 1, in the 0-5 cm layer. In each local, the forest group samples were positioned to the right of the axis. The tendencies observed in NMS were confirmed by the significant difference of all the contrasts between forests of each local and their pairs under the agroecosystems, according to the MRPP technique (Table 4).

The second axis represented, mainly, variations associated to the texture among the studied areas, in other words, those variables more influenced by it (WSA and DOC). Sand, silt and clay content were highly correlated to Axis $2(r=-0.52,0.38$ and 0.41 , respectively, $\mathrm{p}<0.001$ for all of the correlations) and non-correlated to Axis 1 .

The fact that OC and CEC do not correlate with the silt+clay sum is uncommon for soils with low activity clay (FELLER; BEARE, 1997). That aspect, in a certain way, facilitated the comparison among the soils, considering that the texture is an important environmental variable of the coastal tableland soils (ZANGRANDE; REZENDE, 1989) and since its variation did not influence at least part of the studied attributes, mainly $\mathrm{OC}$ and the variables with higher correlation to it. In reality, texture variations among situations of a same place occurred more perceptibly in Umbaúba and in Acajutiba (Table 5 and figure 3). WSA was the only attribute, and only in Umbaúba, to present an site averages under agroecosystems with perceptibly more advantageous values than the sites under forest. In fact, the WSA values are those mainly responsible for UF being the only group under forest to be positioned more to the left of some agroecosystem groups in the NMS technique (Figure 2). The POM and DOC content also contributed to this, but to a lesser degree. In other words, if WSA variations are sensitive to use and management (VASCONCELOS et al., 2010) and they present significant and positive correlation with OC (SILVA et al., 2006b), its extreme dependence on the texture hinders the comparison of data for coastal tableland soils, so varied in texture.

Table 2 - Correlation coefficient ( $\mathrm{r}$ values) between the soil attributes for the $0-5 \mathrm{~cm}$ layer, considering local and land use combinations $(n=60)$.

\begin{tabular}{|c|c|c|c|c|c|c|c|}
\hline Attributes & Silt+Clay & $\mathrm{OC}$ & CEC & $\mathrm{BD}$ & WSA & $\mathrm{MBC}$ & POM \\
\hline OC & -0.11 & & & & & & \\
\hline CEC & -0.21 & $0.83 * *$ & & & & & \\
\hline $\mathrm{BD}$ & 0.12 & $-0.74 * *$ & $-0.54 * *$ & & & & \\
\hline WSA & $0.42 * *$ & $0.42 * *$ & $0.42 * *$ & $-0.37 * *$ & & & \\
\hline MBC & 0.14 & $0.60 * *$ & $0.49 * *$ & $-0.39 * *$ & $0.43 * *$ & & \\
\hline POM & -0.26 & $0.79 * *$ & $0.79 * *$ & $-0.62 * *$ & $0.39 * *$ & $0.43 * *$ & \\
\hline DOC & $0.33 * *$ & $0.56 * *$ & $0.36 * *$ & $-0.53 * *$ & $0.47 * *$ & $0.50 * *$ & $0.45^{* *}$ \\
\hline
\end{tabular}

${ }^{1} \mathrm{OC}=$ organic $\mathrm{C}, \mathrm{CEC}=$ cation exchange capacity, $\mathrm{BD}=$ bulk density, WSA = water stable aggregates, $\mathrm{MBC}=$ microbial biomass $\mathrm{C}, \mathrm{POM}=$ particulate organic matter, e DOC $=$ dissolved organic $\mathrm{C}$.

Correlation values followed by $* *$, significant to $1 \%(\mathrm{p}<0,01)$. 


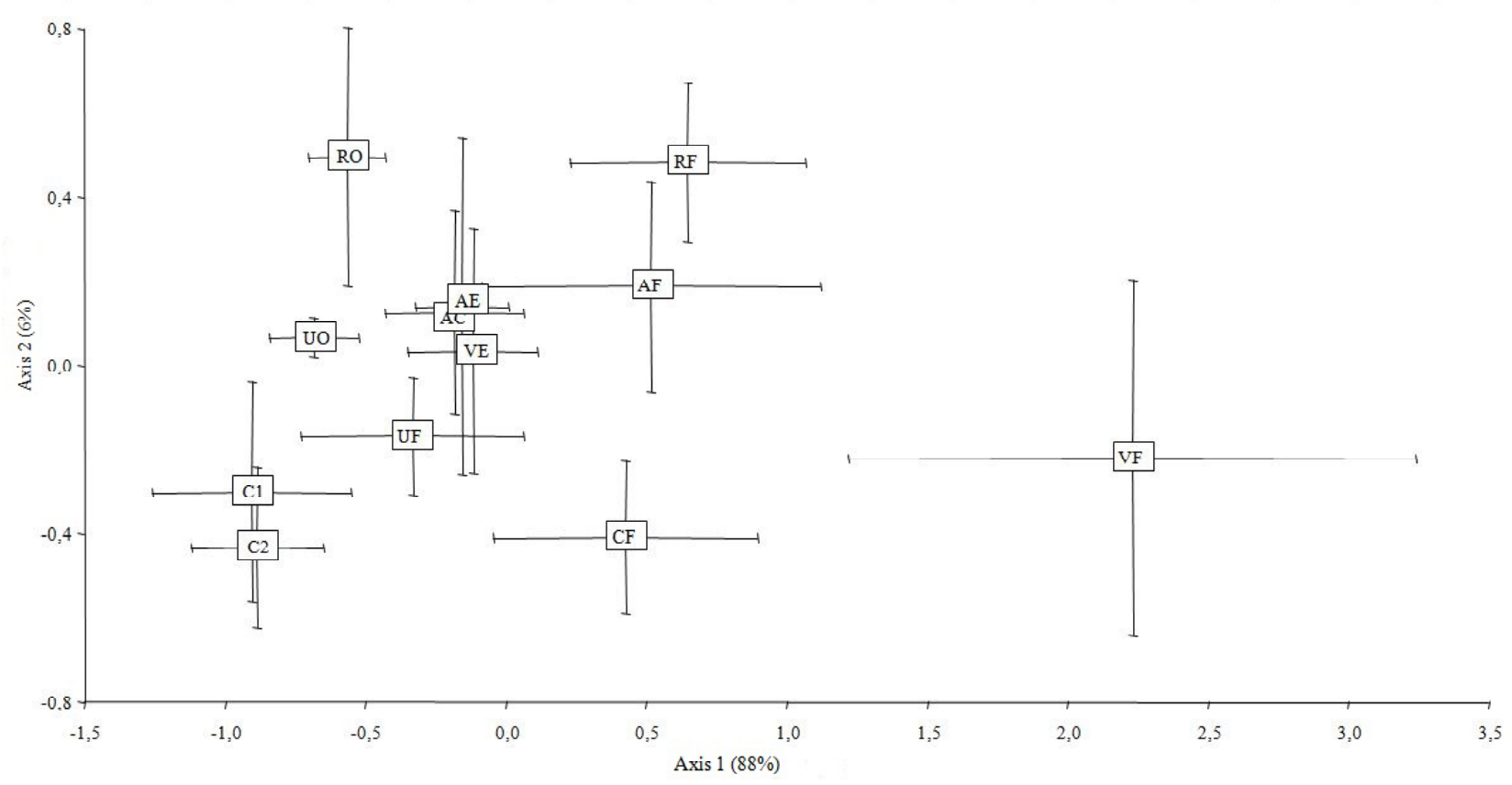

Figure 2 - Ordination obtained by the non-metric multidimensional scaling, representing the similarity between local and land use groups, according to the variation in seven soil attributes (chemical, physical and biological), $0-5 \mathrm{~cm}$ layer samples. Standard deviation for each group $(n=5)$ along the axes 1 and 2 is scaled by the bars. First letter of the code represents the location: C - Coruripe; U - Umbaúba; A - Acajutiba; R - Cruz das Almas, and V - Nova Viçosa. Second letter (or number) of the code represents the land use: $\mathrm{F}$ - forest, 1 - sugarcane management with subsoiling and irrigation, second cut after planting; 2 - sugarcane management with crotalaria, fourth cut after planting; $\mathrm{O}$ - orange; E - eucalyptus; C - coconut.

Table 3 - Correlation coefficients of the 0-5 cm layer variables with the non-metric multidimensional (NMS) scaling axes ordination (Figure 2).

\begin{tabular}{|c|c|c|}
\hline & \multicolumn{2}{|c|}{ Pearson correlation coefficient $(\mathrm{r})$} \\
\hline & Axis 1 & Axis 2 \\
\hline Organic C & $0.93^{* * *}$ & -0.23 \\
\hline Cation exchange capacity & $0.84^{* * *}$ & $-0.34^{* *}$ \\
\hline Bulk density & $-0.78^{* * * *}$ & 0.23 \\
\hline Water stable aggregates & $0.62^{* * * *}$ & $0.38^{* *}$ \\
\hline Microbial biomass $\mathrm{C}$ & $0.68^{* * *}$ & $0.27 *$ \\
\hline Particulate organic matter & $0.83^{* * *}$ & $-0.30^{*}$ \\
\hline Dissolved organic C & $0.70^{* * *}$ & $0.51^{* * *}$ \\
\hline Sand $^{1}$ & $-0.02^{\mathrm{ns}}$ & $-0.52^{* * *}$ \\
\hline $\operatorname{Silt}^{1}$ & $0.09^{\text {ns }}$ & $0.38^{* *}$ \\
\hline Clay $^{1}$ & $-0.08^{\mathrm{ns}}$ & $0.41^{* *}$ \\
\hline
\end{tabular}

Significant: $* \mathrm{p}<0,05 ; * * \mathrm{p}<0,01 ; * * * \mathrm{p}<0,001$. ${ }^{\text {ns}}$ : not significant $(\mathrm{p}>0,05)$.

${ }^{1}$ The sand, silt and clay proportions were not included in the NMS analysis.

Ciênc. agrotec., Lavras, v. 36, n. 6, p. 649-664, nov./dez., 2012 
Table 4 - Soil quality contrasts (0-5 cm layer), described by the combined analysis of seven attributes (chemical, physical and biological), among forests of each location and their pairs in agroecosystems, in accordance with the multi-response permutation procedure (MRPP).

\begin{tabular}{lc}
\hline Contrast & P value \\
\hline Coruripe forest versus sugarcane $1^{1}$ & $0.0035^{* *}$ \\
Coruripe forest versus sugarcane $2^{2}$ & $0.0026^{* *}$ \\
Umbaúba forest versus orange & $0.0084^{* *}$ \\
Acajutiba forest versus eucalyptus & $0.0226^{*}$ \\
Acajutiba forest versus coconut & $0.0163^{*}$ \\
Cruz das Almas forest versus orange & $0.0020^{* *}$ \\
Nova Viçosa forest versus eucalyptus & $0.0029^{* *}$ \\
\hline
\end{tabular}

${ }^{1}$ Management with subsoiling and irrigation, second cut after planting.

${ }^{2}$ Management with crotalaria, fourth cut after planting. Significant: $* \mathrm{p}<0,05 ; * * \mathrm{p}<0,01$.

Even so, it was Acajutiba, and not Umbaúba, that presented the lower significance in the contrasts between agroecosystems (AE and AC) and forest (AF) (Table 4). In that aspect, a perceptible overlap of behavior exists between agroecosystems and forest of Acajutiba for all the attributes considered in NMS, except OC itself (Figure 3).

\section{Samples from 5-20 cm of depth}

Several significant correlations occurred in the superficial samples $(0-5 \mathrm{~cm})$ were not observed in the 5$20 \mathrm{~cm}$ layer (Tables 2 and 6 ). The absence of significant correlation was observed in the pairs of attributes OCDOC, CEC-MBC, CEC-DOC, BD-WSA, BD-MBC, BD-DOC, WSA-POM and POM-DOC, all with high correlation in the $0-5 \mathrm{~cm}$ layer $(\mathrm{p}<0.001)$.

The ordering of the sites by NMS presented a variation of data less concentrated in only one axis than in the $0-5 \mathrm{~cm}$ layer. The first two axes summed $90 \%$ of the data variation, $63 \%$ and $27 \%$ respectively in Axes 1 and 2 (Figure 4). The correlation significant to $5 \%$ between Axis 1 scores and MBC and DOC was less intense than in the 0$5 \mathrm{~cm}$ layer (Tables 3 and 7). The other variables presented the same correlation pattern with this axis as that observed in the $0-5 \mathrm{~cm}$ layer. Thus, the MBC and DOC variables presented, in general, low correlation with the other variables associated to the soil quality in the $5-20 \mathrm{~cm}$ layer. Those two variables are strongly influenced by the deposition of new plant residue (HUANG et al., 2004; VINTHER et al., 2004), which accumulate on the soil surface, which can partly explain their lower sensitivity to the different land uses in the less superficial layer studied. Axis 2, besides increasing the significant correlations that

Table 5 - Soil attributes means $(n=5)$, samples of 0-5 $\mathrm{cm}$ layer of different local and land use groups.

\begin{tabular}{ccccccccc}
\hline Groups & Silt+Clay & Organic C & CEC & BD & WSA & MBC & POM & DOC \\
\hline & dag kg $^{-1}$ & dag kg $^{-1}$ & $\mathrm{cmol}_{\mathrm{c}} \mathrm{dm}^{-3}$ & $\mathrm{~g} \mathrm{~cm}^{-3}$ & $\%$ & $\mathrm{mg} \mathrm{kg}^{-1}$ & $\mathrm{~g} \mathrm{~kg}^{-1}$ & $\mathrm{mg} \mathrm{kg}^{-1}$ \\
$\mathrm{CF}$ & $11 \pm 4$ & $2.53 \pm 0.58$ & $7.97 \pm 1.27$ & $1.21 \pm 0.07$ & $82 \pm 5$ & $103 \pm 41$ & $14.32 \pm 2.49$ & $40 \pm 19$ \\
$\mathrm{C} 1$ & $10 \pm 0$ & $1.59 \pm 0.34$ & $5.63 \pm 1.01$ & $1.46 \pm 0.1$ & $23 \pm 10$ & $49 \pm 16$ & $10.32 \pm 3.34$ & $43 \pm 7$ \\
$\mathrm{C} 2$ & $9 \pm 1$ & $1.81 \pm 0.36$ & $5.14 \pm 1.06$ & $1.38 \pm 0.14$ & $19 \pm 4$ & $40 \pm 18$ & $10.2 \pm 1.69$ & $42 \pm 8$ \\
$\mathrm{UF}$ & $16 \pm 3$ & $2.3 \pm 0.44$ & $5.17 \pm 1.28$ & $1.34 \pm 0.06$ & $37 \pm 10$ & $129 \pm 29$ & $8.39 \pm 0.36$ & $95 \pm 27$ \\
$\mathrm{UO}$ & $21 \pm 3$ & $1.72 \pm 0.33$ & $5.29 \pm 0.66$ & $1.53 \pm 0.04$ & $54 \pm 6$ & $94 \pm 31$ & $9.37 \pm 1.05$ & $45 \pm 14$ \\
$\mathrm{AF}$ & $20 \pm 3$ & $2.57 \pm 0.5$ & $5.81 \pm 1.48$ & $1.23 \pm 0.13$ & $76 \pm 5$ & $88 \pm 15$ & $14.83 \pm 3.6$ & $222 \pm 54$ \\
$\mathrm{AE}$ & $32 \pm 4$ & $1.85 \pm 0.1$ & $5.2 \pm 0.44$ & $1.28 \pm 0.07$ & $75 \pm 5$ & $47 \pm 24$ & $8.92 \pm 2.51$ & $164 \pm 62$ \\
$\mathrm{AC}$ & $19 \pm 4$ & $1.79 \pm 0.36$ & $5.72 \pm 1.19$ & $1.39 \pm 0.05$ & $71 \pm 2$ & $73 \pm 20$ & $11.69 \pm 2.63$ & $145 \pm 42$ \\
$\mathrm{RF}$ & $23 \pm 4$ & $2.49 \pm 0.46$ & $5.79 \pm 0.63$ & $1.22 \pm 0.08$ & $80 \pm 12$ & $198 \pm 37$ & $11.67 \pm 2.58$ & $209 \pm 54$ \\
$\mathrm{RO}$ & $28 \pm 4$ & $1.65 \pm 0.24$ & $5.2 \pm 0.71$ & $1.58 \pm 0.02$ & $77 \pm 13$ & $131 \pm 41$ & $8.91 \pm 1.01$ & $93 \pm 43$ \\
$\mathrm{VF}$ & $16 \pm 2$ & $3.71 \pm 0.84$ & $11.06 \pm 2.46$ & $1.1 \pm 0.06$ & $92 \pm 3$ & $198 \pm 66$ & $22.23 \pm 3.94$ & $238 \pm 112$ \\
$\mathrm{VE}$ & $17 \pm 5$ & $1.99 \pm 0.46$ & $6.65 \pm 1.52$ & $1.41 \pm 0.04$ & $91 \pm 3$ & $80 \pm 13$ & $9.68 \pm 1.87$ & $87 \pm 39$ \\
\hline
\end{tabular}

${ }^{1}$ First letter of the code represents the location: C - Coruripe; U - Umbaúba; A - Acajutiba; R - Cruz das Almas, and V - Nova Viçosa. Second letter (or number) of the code represents the land use: F - forest, 1 - sugarcane management with subsoiling and irrigation, second cut after planting; 2 - sugarcane management with crotalaria, fourth cut after planting; $\mathrm{O}$ - orange; $\mathrm{E}$ - eucalyptus; $\mathrm{C}$ - coconut. ${ }^{2} \mathrm{CEC}=$ cation exchange capacity; $\mathrm{BD}=$ bulk density; $\mathrm{WSA}=$ water stable aggregates; $\mathrm{MBC}=$ microbial biomass $\mathrm{C}, \mathrm{POM}=$ particulate organic matter; $\mathrm{DOC}=$ dissolved organic $\mathrm{C}$. 
already existed in the superficial samples with WSA and DOC, also demonstrated the contribution of MBC (Figure 4 and table 7) and even the high correlation with the sand and clay fraction ( $r=-0.56$ and 0.66 , respectively).

All the contrasts between forests of each local and their pairs under the agroecosystems lost significance degree relative to the 0-5 cm layer (Tables 4 and 8). The contrasts of Cruz das Almas and Nova Viçosa continued significant to $1 \%(\mathrm{p}<0.01)$ and the contrasts of Umbaúba and Acajutiba lost the significant difference (Table 8). Therefore, the behavior of the attributes with the deepening of the samplings, although still regulated by the local plant covering, did not so clearly separate sites under agroecosystems and under forest, within each area. Although that loss of attribute sensitivity with the deepening of the soil is common, it is surprising that this occurs in such a superficial layer $(5-20 \mathrm{~cm})$ for two places (Umbaúba and Acajutiba). Besides a lower significance of their contrasts in the $0-5 \mathrm{~cm}$ layer, the soils of Umbaúba and Acajutiba presented the transition between horizons $A$ and $B$ coincident with the $5-20 \mathrm{~cm}$ layer (data not presented). That small thickness of the horizon A, relative to the other areas (Coruripe, Cruz das Almas and Nova Viçosa), seems to have contributed decisively to the results of the contrasts.
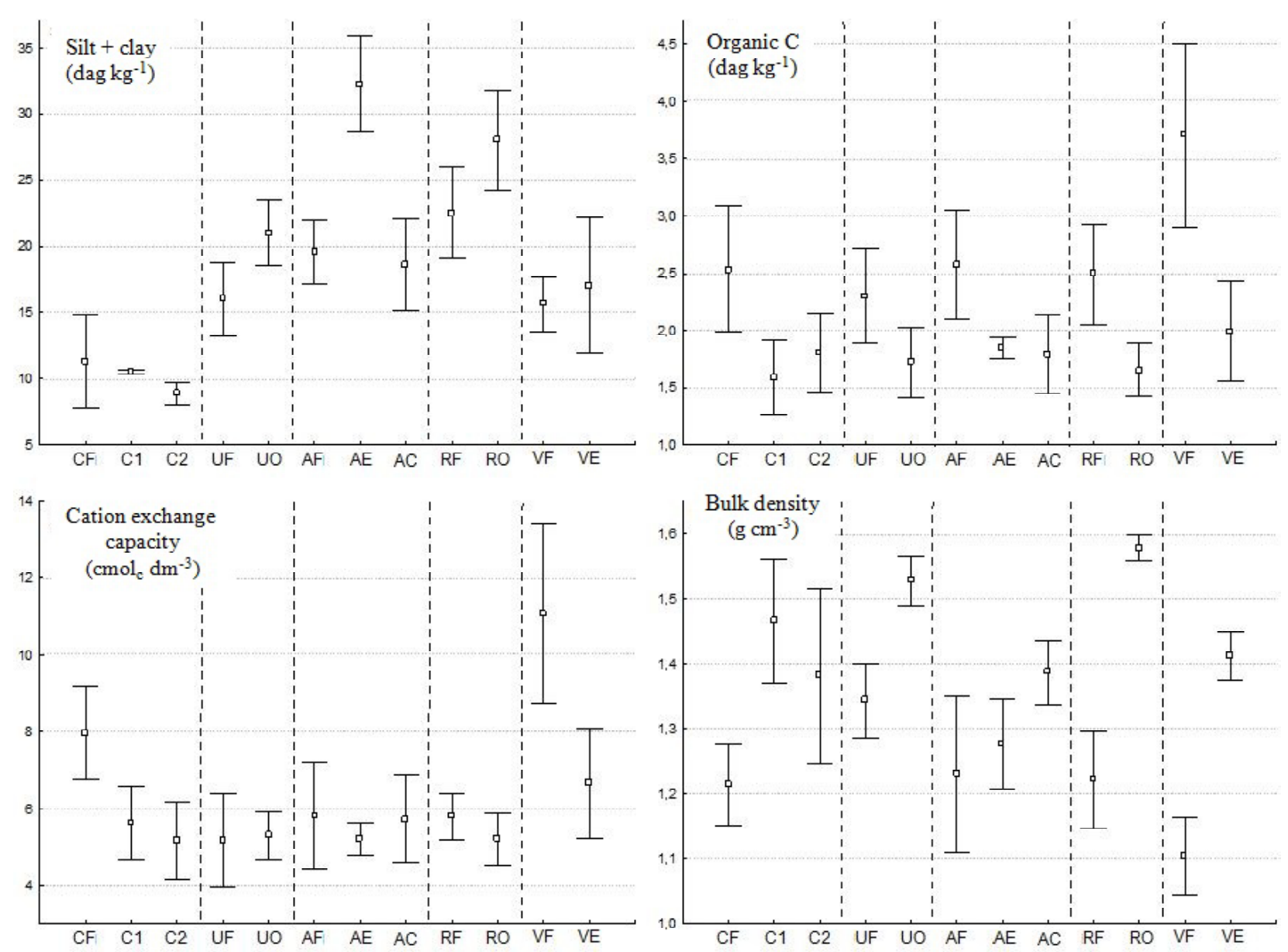

Figure 3 - Mean and standard deviation $(n=5)$ variables, soil samples of 0-5 cm layer. First letter of the code represents the location: C - Coruripe; U - Umbaúba; A - Acajutiba; R - Cruz das Almas, and V - Nova Viçosa. Second letter (or number) of the code represents the land use: F - forest, 1 - sugarcane management with subsoiling and irrigation, second cut after planting; 2 - sugarcane management with crotalaria, fourth cut after planting; $\mathrm{O}$ - orange; E - eucalyptus; C - coconut. 

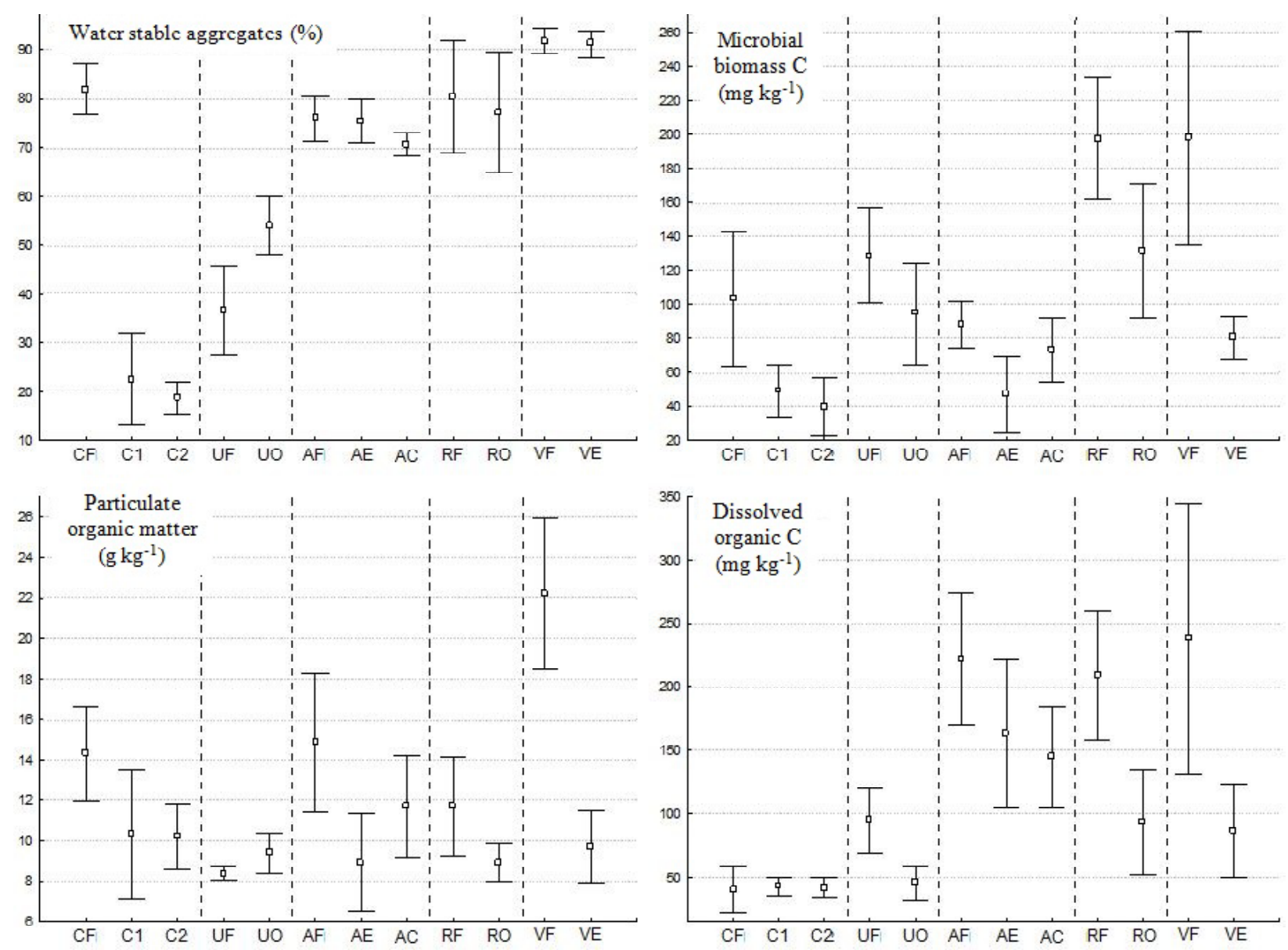

Figure 3 - Continued...

Table 6 - Correlation coefficients (r values) between the soil attributes for the 5-20 cm layer, considering local and land use combinations $(n=60)$.

\begin{tabular}{|c|c|c|c|c|c|c|c|}
\hline Atributos & Silt+Clay & $\mathrm{OC}$ & $\mathrm{CEC}$ & $\mathrm{BD}$ & WSA & $\mathrm{MBC}$ & POM \\
\hline OC & 0.02 & & & & & & \\
\hline CEC & -0.08 & $0.52 * *$ & & & & & \\
\hline $\mathrm{BD}$ & $0.27 *$ & $-0.33^{* *}$ & -0.15 & & & & \\
\hline WSA & $0.46^{* *}$ & $0.36^{* *}$ & $0.32 *$ & -0.22 & & & \\
\hline MBC & $0.27 *$ & $0.32 *$ & 0.06 & -0.14 & $0.44 * *$ & & \\
\hline POM & $-0.32 *$ & $0.42 * *$ & $0.55 * *$ & $-0.32 *$ & 0.18 & -0.01 & \\
\hline DOC & $0.35 * *$ & 0.22 & 0.07 & -0.20 & $0.53 * *$ & $0.47 * *$ & -0.00 \\
\hline
\end{tabular}

${ }^{1} \mathrm{OC}=$ organic $\mathrm{C}, \mathrm{CEC}=$ cation exchange capacity, $\mathrm{BD}=$ bulk density, $\mathrm{WSA}=$ water stable aggregates, $\mathrm{MBC}=$ microbial biomass $\mathrm{C}, \mathrm{POM}=$ particulate organic matter, e DOC $=$ dissolved organic $\mathrm{C}$.

Correlation values followed by $*$ and $* *$, respectively significant to $5 \%(\mathrm{p}<0.05)$ and $1 \%(\mathrm{p}<0.01)$. 


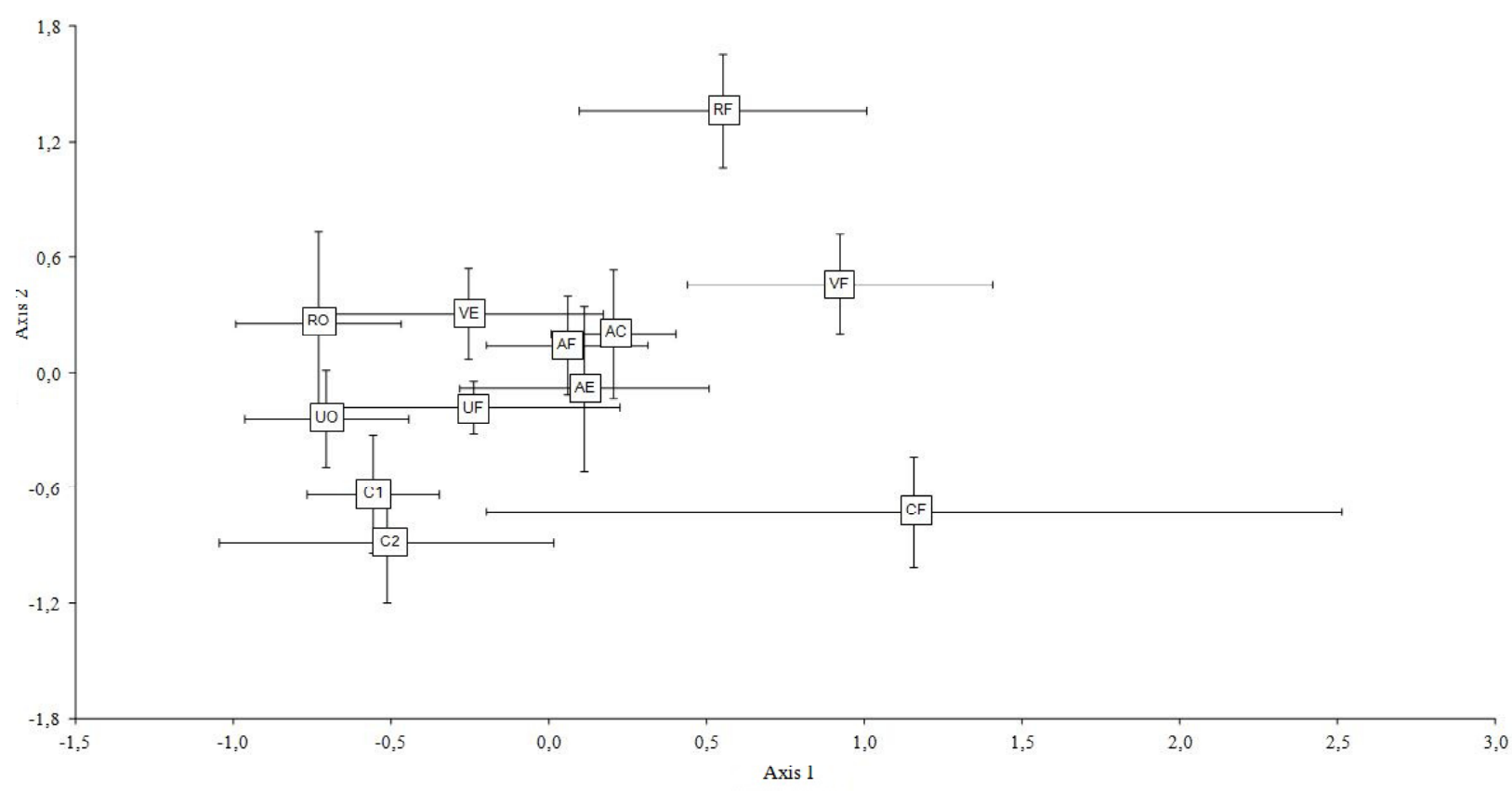

Figure 4 - Ordination obtained by the non-metric multidimensional scaling, representing the similarity between local and land use groups, according to the variation in seven soil attributes (chemical, physical and biological), 5-20 cm layer samples. Standard deviation for each group $(n=5)$ along the axes 1 and 2 is scaled by the bars. First letter of the code represents the location: C - Coruripe; U - Umbaúba; A - Acajutiba; R - Cruz das Almas, and V - Nova Viçosa. Second letter (or number) of the code represents the land use: F - forest, 1 - sugarcane management with subsoiling and irrigation, second cut after planting; 2 - sugarcane management with crotalaria, fourth cut after planting; $\mathrm{O}$ orange; E - eucalyptus; C - coconut.

Table 7 - Correlation coefficients of the 5-20 cm layer variables with the non-metric multidimensional (NMS) scaling axes ordination (Figure 4).

\begin{tabular}{|c|c|c|}
\hline & \multicolumn{2}{|c|}{$\begin{array}{l}\text { Pearson correlation } \\
\text { coefficient (r) }\end{array}$} \\
\hline & Axis 1 & Axis 2 \\
\hline Organic C & $0.78^{* * *}$ & $0.23^{\mathrm{ns}}$ \\
\hline Cation exchange capacity & $0.76^{* * *}$ & $-0.03^{\mathrm{ns}}$ \\
\hline Bulk density & $-0.56^{* * *}$ & $-0.04^{\mathrm{ns}}$ \\
\hline Water stable aggregates & $0.52^{* * *}$ & $0.72^{* * * *}$ \\
\hline Microbial biomass $\mathrm{C}$ & $0.29^{*}$ & $0.77^{* * *}$ \\
\hline Particulate organic matter & $0.75^{* * *}$ & $-0.23^{\mathrm{ns}}$ \\
\hline Dissolved organic C & $0.29^{*}$ & $0.77^{* * *}$ \\
\hline Sand $^{1}$ & $0.14^{\mathrm{ns}}$ & $-0.56^{* * *}$ \\
\hline Silt $^{1}$ & $-0.13^{\mathrm{ns}}$ & $0.03^{\mathrm{ns}}$ \\
\hline Clay $^{1}$ & $-0.09^{\mathrm{ns}}$ & $0.66^{* * *}$ \\
\hline
\end{tabular}

As the 0-5 cm layer, OC and CEC continued not correlating with the silt+clay sum. The finer texture of the RO sites, relative to the RF sites (37 and 23 dag $\mathrm{kg}^{-1}$ of silt+clay, respectively) did not impede RF sites, in Axis 2, from being very isolated from $\mathrm{RO}$ and of all the other sites, considering the high correlation between clay and Axis 2 of NMS. To understand the position of the RF group in upper part of the order, it should be observed, mainly, the average MBC and DOC values (Table 9 and figure 5).

\section{The entire data}

All of the groups of studied soils presented middle class OC content in the 0-20 cm layer, according to classes defined by Alvarez et al. (1999). Those contents are common for coastal tableland soils, and may vary upwards in soils under forest (SILVA et al., 2006b) and downwards in soils under agricultural use (FERNANDES et al., 2011; PACHECO; CANTALICE, 2011). The V values in the $0-20 \mathrm{~cm}$ layer presented an overall average of $62 \%$, with only the RF group presenting low content (33\%).

Ciênc. agrotec., Lavras, v. 36, n. 6, p. 649-664, nov./dez., 2012 
Table 8 - Soil quality contrasts (5-20 cm layer), described by the combined analysis of seven attributes (chemical, physical and biological), among forests of each location and their pairs in agroecosystems, in accordance with the multi-response permutation procedure (MRPP).

\begin{tabular}{lc}
\hline Contrast & $P$ Value \\
\hline Coruripe forest versus sugarcane $1^{1}$ & $0.0125^{*}$ \\
Coruripe forest versus sugarcane $2^{2}$ & $0.0273^{*}$ \\
Umbaúba forest versus orange & 0.1734 \\
Acajutiba forest versus eucalyptus & 0.8032 \\
Acajutiba forest versus coconut & 0.6238 \\
Cruz das Almas forest versus Orange & $0.0022^{* *}$ \\
Nova Viçosa forest versus eucalyptus & $0.0058^{* *}$ \\
\hline
\end{tabular}

${ }^{1}$ Management with subsoiling and irrigation, second cut after planting.

${ }^{2}$ Management with crotalaria, fourth cut after planting.

Significant: $* \mathrm{p}<0,05 ; * * \mathrm{p}<0,01$.

The $\mathrm{m}$ values are low or very low for all the groups (Table 10). Those values of $\mathrm{V}$ and $\mathrm{m}$ cause the presumption that the absence of nutrient reserves in those soils, an inherited characteristic of material origin basically exempt from primary minerals (MELO et al., 2002), can be lessened by the flat landscapes and the soils with a low subsurface infiltration rate (SILVA; RIBEIRO, 1997; LIMA NETO et al., 2009; RESENDE et al., 2011). Those characteristics can facilitate the recycling of nutrients in natural systems (forest) and decelerate the exit of nutrients introduced through manuring (lower deep lixiviation rates) in the perennial to semiperennial agricultural systems (ZANGRANDE; REZENDE, 1989).

Although the texture influences the agricultural behavior of the local soils, increasing the expression of the subsurface cohesive character as the clay content of the studied layer increases (GOMES et al., 2008), this was not preponderant for the behavior of the attributes that most influenced the first NMS axis in the two layers, that one with strong OC and associated variables influence. Thus, the relatively sandier soils of Coruripe, mainly in the $5-20 \mathrm{~cm}$ layer, did not stand out in the array due to this aspect, which is related to the absence of correlation between the OC and silt+clay content, which may be a consequence of the essentially kaolinitic mineralogy of the clay fraction of the studied soils. This mineralogy imposes weak subangular blocky structure, low porosity and low permeability to the soils (FERREIRA et al., 1999; RESENDE et al., 2011). These characteristics may bring consequences to the stock of OC in the soil. It is likely that in the coastal tablelands soils, the protective effect of the fine fraction on the OC be overcome by a more effective physical condition which includes sandier texture and thicker surface horizons. The model would begin to be changed if the clay increase in depth does not occur, or even occurs at depths that may result in a decrease in the soil moisture regime.

Table 9 - Soil attributes means $(n=5)$, samples of 5-20 cm layer of different local and land use groups.

\begin{tabular}{lcccccccc}
\hline Groups & Silt+Clay & Organic C & CEC & BD & WSA & MBC & POM & DOC \\
\hline & dag kg $^{-1}$ & dag kg$^{-1}$ & $\mathrm{cmol}_{\mathrm{c}} \mathrm{dm}^{-3}$ & $\mathrm{~g} \mathrm{~cm}^{-3}$ & $\%$ & $\mathrm{mg} \mathrm{kg}^{-1}$ & $\mathrm{~g} \mathrm{~kg}^{-1}$ & $\mathrm{mg} \mathrm{kg}^{-1}$ \\
$\mathrm{CF}$ & $12 \pm 2$ & $1.86 \pm 0.61$ & $5.79 \pm 2.89$ & $1.40 \pm 0.13$ & $66 \pm 12$ & $60 \pm 27$ & $11.81 \pm 3.09$ & $25 \pm 8$ \\
$\mathrm{C} 1$ & $13 \pm 4$ & $1.28 \pm 0.14$ & $4.75 \pm 0.26$ & $1.52 \pm 0.17$ & $25 \pm 7$ & $49 \pm 19$ & $7.07 \pm 1.56$ & $53 \pm 8$ \\
$\mathrm{C} 2$ & $9 \pm 2$ & $1.26 \pm 0.52$ & $4.50 \pm 1.13$ & $1.45 \pm 0.12$ & $26 \pm 5$ & $13 \pm 8$ & $6.38 \pm 0.39$ & $50 \pm 14$ \\
$\mathrm{UF}$ & $25 \pm 3$ & $1.63 \pm 0.27$ & $4.01 \pm 0.84$ & $1.51 \pm 0.08$ & $40 \pm 10$ & $70 \pm 31$ & $7.15 \pm 0.78$ & $89 \pm 20$ \\
$\mathrm{UO}$ & $27 \pm 3$ & $1.39 \pm 0.29$ & $4.35 \pm 0.69$ & $1.60 \pm 0.06$ & $46 \pm 8$ & $51 \pm 23$ & $5.35 \pm 0.68$ & $37 \pm 6$ \\
$\mathrm{AF}$ & $32 \pm 5$ & $1.74 \pm 0.31$ & $4.63 \pm 0.49$ & $1.51 \pm 0.06$ & $72 \pm 11$ & $45 \pm 18$ & $7.86 \pm 1.42$ & $117 \pm 37$ \\
$\mathrm{AE}$ & $33 \pm 7$ & $1.64 \pm 0.13$ & $4.97 \pm 0.36$ & $1.38 \pm 0.09$ & $73 \pm 5$ & $57 \pm 17$ & $6.60 \pm 0.67$ & $126 \pm 64$ \\
$\mathrm{AC}$ & $24 \pm 2$ & $1.42 \pm 0.21$ & $5.09 \pm 0.8$ & $1.49 \pm 0.09$ & $69 \pm 19$ & $31 \pm 10$ & $9.11 \pm 1.47$ & $113 \pm 46$ \\
$\mathrm{RF}$ & $23 \pm 1$ & $1.83 \pm 0.39$ & $4.36 \pm 0.6$ & $1.35 \pm 0.04$ & $84 \pm 6$ & $155 \pm 38$ & $6.98 \pm 1.39$ & $193 \pm 40$ \\
$\mathrm{RO}$ & $37 \pm 2$ & $1.20 \pm 0.15$ & $4.84 \pm 0.8$ & $1.66 \pm 0.05$ & $69 \pm 13$ & $81 \pm 35$ & $5.55 \pm 1.2$ & $70 \pm 50$ \\
VF & $26 \pm 2$ & $1.61 \pm 0.17$ & $6.60 \pm 1.18$ & $1.44 \pm 0.08$ & $89 \pm 3$ & $91 \pm 18$ & $9.59 \pm 1.41$ & $157 \pm 64$ \\
VE & $22 \pm 5$ & $1.41 \pm 0.36$ & $4.53 \pm 0.91$ & $1.49 \pm 0.06$ & $86 \pm 7$ & $59 \pm 25$ & $5.87 \pm 0.99$ & $84 \pm 45$ \\
\hline
\end{tabular}

${ }^{1}$ First letter of the code represents the location: C - Coruripe; U - Umbaúba; A - Acajutiba; R - Cruz das Almas, and V - Nova Viçosa. Second letter (or number) of the code represents the land use: F - forest, 1 - sugarcane management with subsoiling and irrigation, second cut after planting; 2 - sugarcane management with crotalaria, fourth cut after planting; O - orange; E - eucalyptus; C - coconut. ${ }^{2} \mathrm{CEC}=$ cation exchange capacity; $\mathrm{BD}=$ bulk density; $\mathrm{WSA}=$ water stable aggregates; $\mathrm{MBC}=$ microbial biomass $\mathrm{C}, \mathrm{POM}=$ particulate organic matter; DOC $=$ dissolved organic $\mathrm{C}$. 

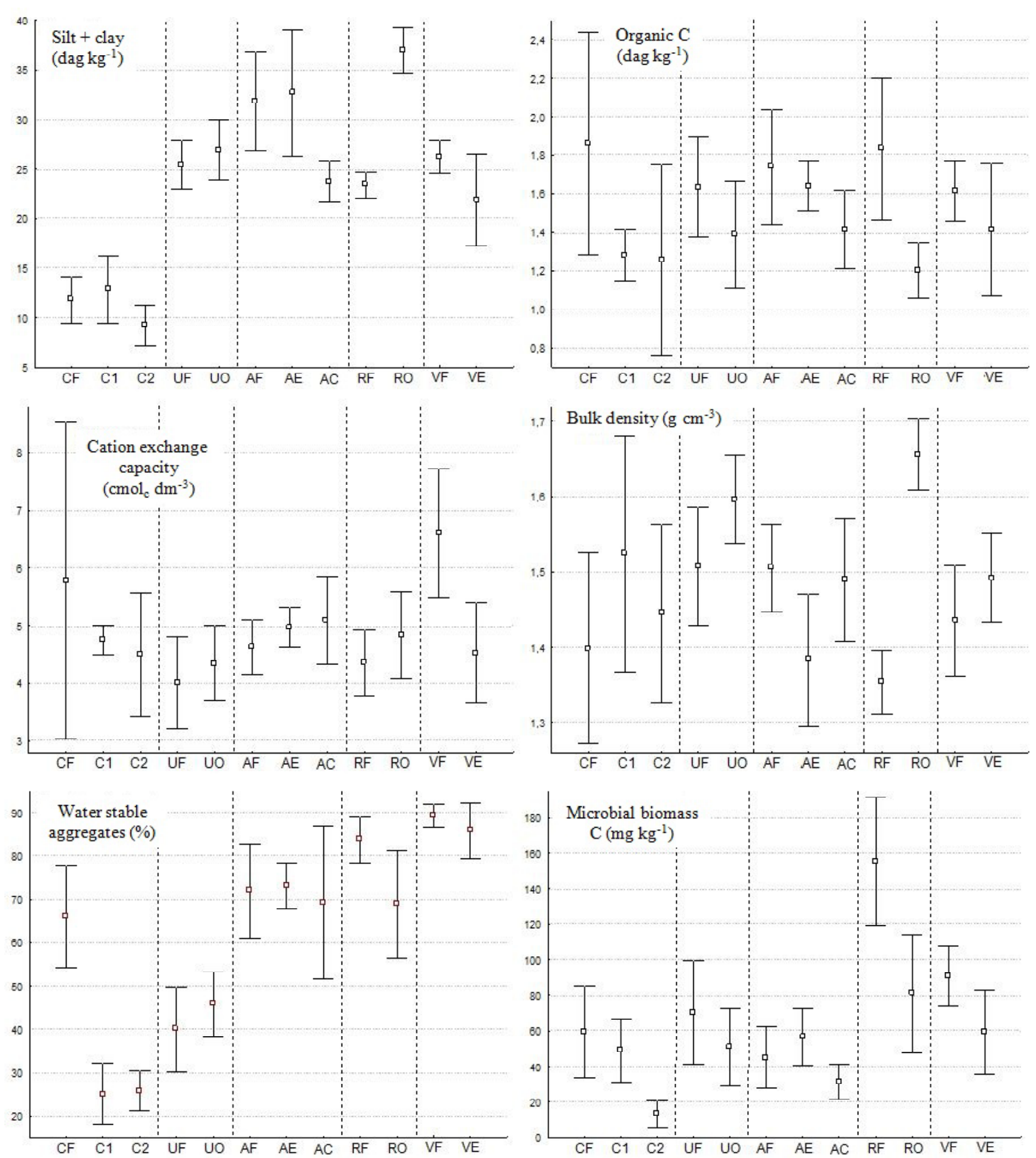

Figure 5 - Mean and standard deviation $(\mathrm{n}=5)$ variables, soil samples of 5-20 $\mathrm{cm}$ layer. First letter of the code represents the location: C - Coruripe; U - Umbaúba; A - Acajutiba; R - Cruz das Almas, and V - Nova Viçosa. Second letter (or number) of the code represents the land use: $\mathrm{F}$ - forest, 1 - sugarcane management with subsoiling and irrigation, second cut after planting; 2 - sugarcane management with crotalaria, fourth cut after planting; $\mathrm{O}$ - orange; E - eucalyptus; C - coconut.

Continue... 

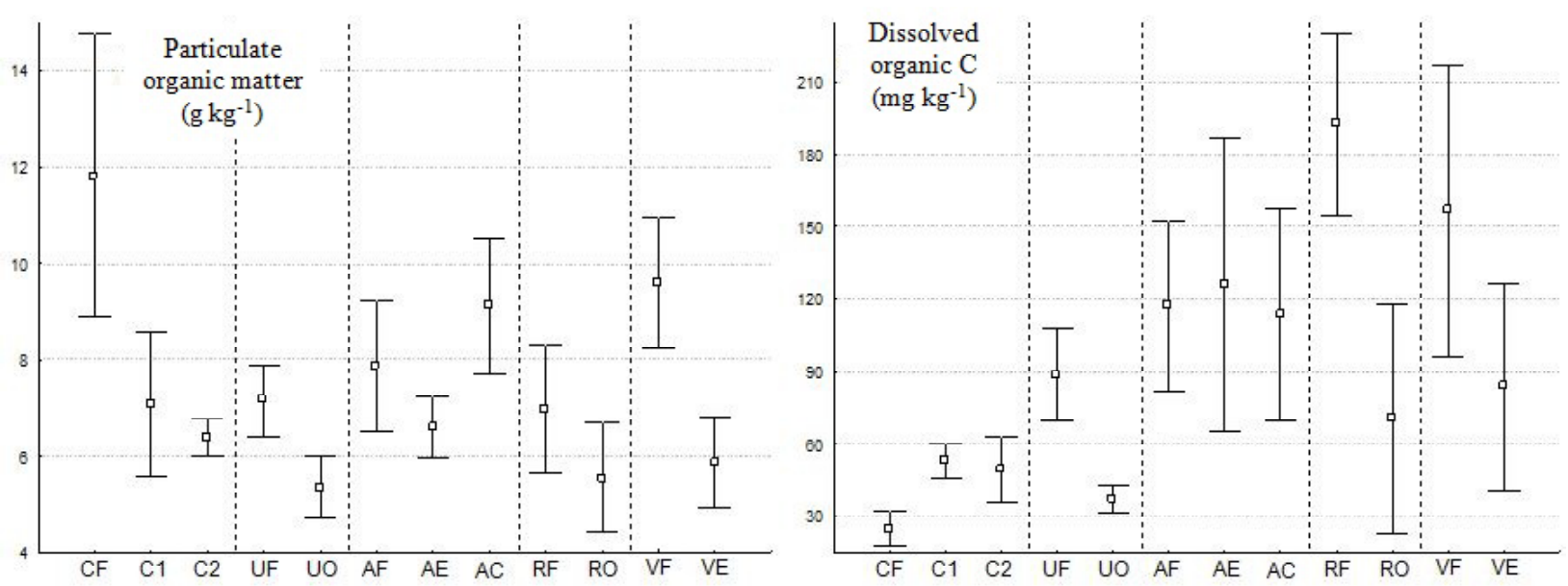

Figure 5 - Continued...

Table 10 - Mean values $(\mathrm{n}=5)$ of silt+clay, organic carbon $(\mathrm{OC})$, base saturation $(\mathrm{V})$ and $\mathrm{Al}$ saturation $(\mathrm{m})$ of $0-20 \mathrm{~cm}$ layer soil samples from different local and land use groups.

\begin{tabular}{|c|c|c|c|c|}
\hline Groups & silt+clay & OC & $\mathrm{V}$ & $\mathrm{m}$ \\
\hline & \multicolumn{2}{|c|}{ dag kg ${ }^{-1}$} & \multicolumn{2}{|c|}{$\%$} \\
\hline Coruripe forest (CF) & 12 & 2.03 & 57 & 5 \\
\hline Coruripe sugarcane $1(\mathrm{C} 1)^{1}$ & 12 & 1.36 & 72 & 1 \\
\hline Coruripe sugarcane $2(\mathrm{C} 2)^{1}$ & 9 & 1.40 & 68 & 1 \\
\hline Umbaúba forest (UF) & 23 & 1.80 & 59 & 13 \\
\hline Umbaúba orange (UO) & 25 & 1.47 & 66 & 3 \\
\hline Acajutiba forest (AF) & 29 & 1.95 & 45 & 17 \\
\hline Acajutiba eucalyptus (AE) & 33 & 1.69 & 57 & 9 \\
\hline Acajutiba coconut (AC) & 22 & 1.51 & 78 & 0 \\
\hline Cruz das Almas forest (RF) & 23 & 2.00 & 33 & 28 \\
\hline Cruz das Almas orange (RO) & 35 & 1.31 & 68 & 1 \\
\hline Nova Viçosa forest (VF) & 24 & 2.14 & 72 & 1 \\
\hline Nova Viçosa eucalyptus (VE) & 21 & 1.56 & 60 & 8 \\
\hline Global mean & 22 & 1.68 & 62 & 6 \\
\hline
\end{tabular}

${ }^{1} \mathrm{C} 1$ - management with subsoiling and irrigation, second cut after planting; $\mathrm{C} 2$ - management with crotalaria, fourth cut after planting.

Another aspect with strong influence on the agricultural potential and also on the forest type (subperennial or semi-deciduous) that occurs in the universe studied, the difference of the distribution of the precipitation among sites, did not show an apparent relationship with the obtained results. The almost absence of periods with hydric deficit in Cruz das Almas and Nova Viçosa reduces the water deficiency and also the expression of the cohesive character of both sites, relative to Coruripe,
Umbaúba and Acajutiba. On the other hand, the Coruripe soils, for being much sandier, tend to express higher degrees of cohesion at greater depths. As such, for the studied soils, the precipitation differences were not enough to evidence the importance of the climate on the regulation of OC of natural ecosystems (ALVAREZ; LAVADO 1998), because it determines the vegetation type, besides the amount and quality of the organic matter that is incorporate into the soil (ZORNOZA et al., 2007). 
The results confirmed the importance of OC in soil quality indicator studies, an aspect already pointed to by many authors. It can be monitored over time to determine if the quality of the soil is getting better, worsening or remaining stable (SHUKLA et al., 2006). For all of the soils of the cultivated sites (agroecosystems), it is expected that the loss of $\mathrm{OC}$ is associated to the net reduction of the organic matter input in the system and the loss of soil protection against erosion, besides the increase of the decomposition rate as a consequence of cultivation (MOSCATELLI et al., 2007). The erosion is locally minimized, for the flat relief of all of the sites. The absence of annual tilling (perennial to semi-perennial crops) also minimizes the decomposition rate compared to the management with annual soil tilling. The other attributes sensitive to soil use and management and that correlate with $\mathrm{OC}$, also present that type of behavior well documented by the literature (SHUKLA et al, 2006; ZORNOZA et al., 2007; COSTA et al., 2009; FERNANDES et al., 2011). This happens, for example, with the decrease in the MBC content in cultivated soils compared to the unaltered and to the strong MBC-OC relationship (SAVIOZZI et al., 2001).

\section{CONCLUSIONS}

In all the sites, the vegetation with native forest presents higher chemical, physical and microbiological soil quality attributes than the respective agricultural systems, mainly in the $0-5 \mathrm{~cm}$ layer, as demonstrated by the nonmetric multi-dimensional scaling technique (NMS). The tendencies observed in NMS were confirmed by the significant difference of contrasts between forests of each local and their pairs under the agroecosystems, according to the multi-response permutation procedure technique.

For the two layers, the attribute that explains most of the data variation in NMS is organic C.

The set of analyzed variables is sensitive to differentiate the quality of the soils under perennial and semi-perennial land uses from their counterparts under native vegetation of the coastal tableland landscapes.

\section{REFERENCES}

ALVAREZ, R.; LAVADO, R. S. Climate, organic matter and clay content relationships in the Pampa and Chaco soils, Argentina. Geoderma, Amsterdan, v.83, n.1/2, p.127-141, 1998 .

ALVAREZ, V. V. H. et al. Interpretação dos resultados das análises de solos. In: RIBEIRO, A. C.; GUIMARÂES, P. T. G;; ALVAREZ, V. H. (Ed.) Rec211omendações para o uso de corretivos e fertilizantes em Minas Gerais - $5^{\text {a }}$ aproximação. Viçosa. Comissão de Fertilidade do Solo do Estado de Minas Gerais, p.25-32, 1999.

AMELUNG, W.; ZECH, W.; FLACH, K.W. Carbon, nitrogen and sulfur pools in particle-size fractions as influenced by climate. Soil Science Society of America Journal, Madison, v.62, n.1, p.172-181, 1998.

BARTLETT, R. J.; ROSS, S. D. Colorimetric determination of oxidizable carbon in acid soil solutions. Soil Science Society of America Journal, Madison, v.52, n.4, p.11911192, 1988.

CHAER, G. M. et al. Shifts in microbial community composition and physiological profiles across a gradient of induced soil degradation. Soil Science Society of America Journal, Madison, v.73, n.4, p.13271334, 2009.

CHAPMAN, S. J.; CAMPBELL, C. D.; PURI, G. Native woodland expansion: soil chemical and microbiological indicators of change. Soil Biology \& Biochemistry, Brisbane, v.35, n.6, p.753-764, 2003.

CINTRA, F. L. D. et al. Efeito de volumes de água de irrigação no regime hídrico de solo coeso dos tabuleiros e na produção de coqueiro. Revista Brasileira de Ciência do Solo, Viçosa, v.33, n.4, p.1041-1051, 2009.

CORRÊA, M. M. et al. Caracterização física, química, mineralógica e micromorfológica de horizontes coesos e fragipãs de solos vermelhos e amarelos do ambiente tabuleiros costeiros. Revista Brasileira de Ciência do Solo, Viçosa, v.32, n.1, p.297-313, 2008.

COSTA, O. V. et al Estoque de carbono do solo sob pastagem em área de tabuleiro costeiro no sul da Bahia.

Revista Brasileira de Ciência do Solo, Viçosa, v.33, n.5, p.1137-1145, 2009.

DUARTE, M. N. et al. Mineralogia, químicae micromorfologia de solos de uma microbacia nos Tabuleiros Costeiros do Espírito Santo. Pesquisa Agropecuária Brasileira, Brasília, v.35, n.6, p.1237-1250, 2000.

EMPRESA BRASILEIRA DE PESQUISA AGROPECUÁRIA-EMBRAPA. Manual de métodos de análise de solo. $2 \mathrm{a}$ ed. Rio de Janeiro, EMBRAPA-CNPS, 1997.212p. (EMBRAPA-CNPS. Documentos; 1). 
EMPRESA BRASILEIRA DE PESQUISA AGROPECUÁRIA-EMBRAPA. III Plano Diretor da Embrapa Tabuleiros Costeiros 2004-2007. Aracaju, Embrapa Tabuleiros Costeiros, 2005. 40p. (Documentos/ Embrapa Tabuleiros Costeiros, 73).

FELLER, C.; BEARE, M. H. Physical control of soil organic matter dynamics in the tropics. Geoderma, Amsterdan, v.79, n.1/4, p.69-116, 1997.

FERNANDES, M. F. et al. Short-term response of physical and chemical aspects of soil quality of a kaolinitic Kandiudalfs to agricultural practices and its association with microbiological variables. Agriculture, Ecosystems \& Environment, Zürich, v.142, n.3/4, p.419427, 2011.

FERREIRA, M. M.; FERNANDES, B.; CURI, N. Mineralogia da fração argila e estrutura de Latossolos da região Sudeste do Brasil. Revista Brasileira de Ciência do Solo, Viçosa, v.23, n.3, p.507-514, 1999.

GIAROLA, N. F. B. et al. Mineralogia e cristalografia da fração argila de horizontes coesos de solos nos tabuleiros costeiros. Revista Brasileira de Ciência do Solo, Viçosa, v.33, n.1, p.33-40, 2009.

GOMES, J. B. V. et al. Análise de componentes principais de atributos físicos, químicos e mineralógicos de solos do bioma cerrado. Revista Brasileira de Ciência do Solo, Viçosa, v.28, n.1, p.137-153, 2004.

GOMES, J. B. V. et al. Variabilidade espacial de atributos de solos em unidades de manejo em área piloto de produção integrada de coco. Revista Brasileira de Ciência do Solo, Viçosa, v.32, n.6, p.2471-2482, 2008.

GOMES, J. B. V. et al. Relações entre atributos do solo e atividade de formigas em restingas. Revista Brasileira de Ciência do Solo, Viçosa, v.34, n.1, p.67-78, 2010.

HUANG, Y. et al. Nitrous oxide emissions as influenced by amendment of plant residues with different $\mathrm{C}: \mathrm{N}$ ratios. Soil Biology \& Biochemistry, Brisbane, v.36, n.6, p.973-981, 2004.

JACOMINE, P. K. T. Evolução do conhecimento sobre solos coesos no Brasil. In: CINTRA, L. F. D.; ANJOS, J. L. dos; IVO, W. M. P. de M. (Eds.). Workshop Coesão em Solos dos Tabuleiros Costeiros. Aracaju, Embrapa Tabuleiros Costeiros, 2001. p.19-46.

JUO, A. S. R.; FRANZLUEBBERS, K. Tropical soils: Properties and management for sustainable agriculture. Oxford, Oxford University Press, 2003. 281p.

LANI, J. L. (Coord.) Atlas de ecossistemas do Espirito Santo. Vitória, SEMA; Viçosa, UFV, 2008. 504p.

LIMA NETO, J. de A. et al. Caracterização e gênese do caráter coeso em Latossolos Amarelos e Argissolos dos tabuleiros costeiros do estado de Alagoas. Revista Brasileira de Ciência do Solo, Viçosa, v.33, n.4, p.10011011, 2009.

McCUNE, B.; MEFFORD, M. J. PC-ORD. Multivariate analysis of ecological data, Version 4. Oregon, $\mathrm{MjM}$ Software Design, p.23, 1999.

MELO, V. F. et al. Mineralogia das frações areia, silte e argila de sedimentos do Grupo Barreiras no município de Aracruz, Estado do Espírito Santo. Revista Brasileira de Ciência do Solo, Viçosa, v.26, n.1, p.29-41, 2002.

MIELKE, P. W.; BERRY, K. J.; JOHNSON, E. S. Multiresponse permutation procedures for a priori classifications. Communications in Statistics Theory and Methods, Philadelphia, v.5, n.14, p.14091424, 1976.

MOSCATELLI, M. C. et al. Microbial indicators related to soil carbon in Mediterranean land use systems. Soil \& Tillage Research, Amsterdan, v.97, n.1, p.51-59, 2007.

PACHECO, E. P.; CANTALICE, J. R. B. Análise de trilha no estudo dos efeitos de atributos físicos e matéria orgânica sobre a compressibilidade e resistência à penetração de um Argissolo cultivado com cana-deaçúcar. Revista Brasileira de Ciência do Solo, Viçosa, v.35, n.2, p.417-428, 2011.

RESENDE, M. et al. Mineralogia de solos brasileiros: interpretação e aplicações. 2. ed. Lavras, UFLA, 2011. 206p.

SANT'ANNA, S. A. C. et al. Evaluation of soil quality indicators in sugarcane management in sandy loam soil. Pedosphere, Nanjing, v.19, n.3, p.312-322, 2009. 
SAVIOZZI, A. et al. A comparison of soil quality in adjacent cultivated, forest, and native grassland soils. Plant and Soil, Crawley, v.233, n.2, p.251-259, 2001.

SHUKLA, M. K.; LAL, R.; EBINGER, M. Determining soil quality indicators by factor analysis. Soil \& Tillage Research, Amsterdan, v.87, n.2, p.194-204, 2006.

SILVA, F. B. R. et al. Zoneamento agroecológico do Nordeste: diagnóstico do quadro natural e agrossocioeconômico. v.2. Petrolina, Embrapa-CPATSA e Embrapa-CNPS, 1993.387p.

SILVA, A. J. N.; RIBEIRO, M. R. Caracterização de Latossolo Amarelo sob cultivo contínuo de cana-deaçúcar no Estado de Alagoas: atributos morfológicos e físicos. Revista Brasileira de Ciência do Solo, Viçosa, v.21, n.4, p.677-684, 1997.

SILVA, A. J. N. et al. Alterações físicas e químicas de um Argissolo Amarelo sob diferentes sistemas de uso e manejo. Revista Brasileira de Engenharia Agrícola e Ambiental, Campina Grande, v.10, n.1, p.76-83, $2006 a$.

SILVA, A. J. N.; CABEDA, M. S. V.; CARVALHO, F. G. Matéria orgânica e propriedades físicas de um Argissolo Amarelo coeso sob sistemas de manejo com cana-de- açúcar. Revista Brasileira de Engenharia Agrícola e Ambiental, Campina Grande, v.10, n.3, p.579-585, 2006 b.

VANCE, E. D.; BROOKES, P. C.; JENKINSON, D. S. An extraction method for measuring soil microbial biomass C. Soil Biology \& Biochemistry, Brisbane, v.19, n.6, p.703-707, 1987.

VASCONCELOS, R. F. B. et al. Estabilidade de agregados de um Latossolo Amarelo Distrocoeso de tabuleiro costeiro sob diferentes aportes de resíduos orgânicos da cana-de-açúcar. Revista Brasileira de Ciência do Solo, Viçosa, v.34, n.2, p.309-316, 2010.

VINTHER, F. P.; HANSEN, E. M.; OLESEN, J. E. Effects of plant residues on crop performance, $\mathrm{N}$ mineralisation and microbial activity including field $\mathrm{CO}_{2}$ and $\mathrm{N}_{2} \mathrm{O}$ fluxes in unfertilized crop rotations. Nutrient Cycling in Agroecosystems, Bonn, v.70, n.2, p.189-199, 2004.

ZANGRANDE, M. B.; REZENDE, S. B. Características de um Podzólico Vermelho-Amarelo abrúptico dos platôs litorâneos do norte do Espírito Santo. Revista Ceres, Viçosa, v.36, n.204, p.147-172, 1989.

ZORNOZA, R. et al. Soil properties under natural forest in the Alicante Province of Spain. Geoderma, Amsterdan, v.142, n.3/4, p.334-341, 2007. 